\title{
Evaluation of Some Herbicide Treatments for Controlling Tall Larkspur
}

\section{E. H. CRONIN}

Highlight: Esters or the amine formulation of silvex and 2,4,5-T were equally toxic to tall larkspur. Repeated annual treatments with 2,4,5-T, silvex, dicamba, and picloram proved equally effective for controlling tall larkspur. Applications of 2,4,5-T (or silvex) at $4 \mathrm{lb} /$ acre for each of two summers were the most economical of the various effective treatments evaluated.

Tall larkspur (Delphinium barbeyi Huth.) causes severe and sometimes catastrophic losses of cattle grazing the subalpine ranges of Utah. The losses occur because tall larkspur grows on relatively small, localized areas in the subalpine zone where it receives an almost continuous water supply during the summer (Cronin, 1971). Tall larkspur is palatable to cattle (Kingsbury, 1964). Repeated or split applications of 2,4,5-T [(2,4,5trichlorophenoxy)-acetic acid] and silvex $[(2,4,5$-trichlorophenoxy) propionic acid] have effectively reduced densities of tall larkspur for periods of 5 or more years (Cronin and Nielsen, 1972).

Controlling tall larkspur with herbicides is the best established method that is effective and without serious adverse ecological effects to the plant community or soil (Cronin and Nielsen, 1972). Therefore, it is desirable to study the effectiveness of herbicides other than 2,4,5-T and

The author is plant physiologist, Utah-IdahoMontana Area, Western Region, Agricultural Research Service, U.S. Department of Agriculture, Logan, Utah.

The work represents cooperative investigations by Utah-Idaho-Montana Area, Western Region, Agr. Res. Serv., U.S. Dep. Agr., and Utah Agricultural Experiment Station, Logan, Utah. Utah Agricultural Experiment Station Paper 1451.

This is a report on the current status of research involving use of certain chemicals that require registration under the Federal Insecticide, Fungicide, and Rodenticide Act. It does not contain recommendations for the use of such chemicals, nor does it imply that the uses discussed have been registered. All uses of these chemicals must be registered by the appropriate state and federal agencies before they can be recommended.

Manuscript received June 30, 1973. silvex for controlling tall larkspur in event use of a particular herbicide is banned. This need was demonstrated by a temporary ban on the use of 2,4,5-T during the summer of 1970 by the Forest Service. Ecological justification for alternative herbicide treatments also exists. Toofrequent application of a single herbicide may selectively promote increases of other undesirable plants resistant to the herbicide.

Under some conditions, costs of application may represent the major expense of herbicide treatment. Also, each annual application can multiply the cost of the treatment. Therefore, a comprehensive study of the effectiveness of various annual treatments was undertaken in 1965, using the most promising herbicides evaluated to that date.

\section{Methods and Materials}

Study plots were located at the head of Manti Canyon on the Wasatch Plateau in central Utah. All plots were within tallforb communities (Ellison, 1954) on snowdrift areas with high and relatively uniform densities of tall larkspur (Fig. 1).

All herbicide treatments were applied to 8 - by 33-ft plots with a compressed-air knapsack sprayer. Each herbicide was applied, in $40 \mathrm{gpa}$ of aqueous solution, when tall larkspur was 8 to 12 inches high and racemes were less than $1 / 2$ inch long. The dogtooth violet (Erythronium grandi-

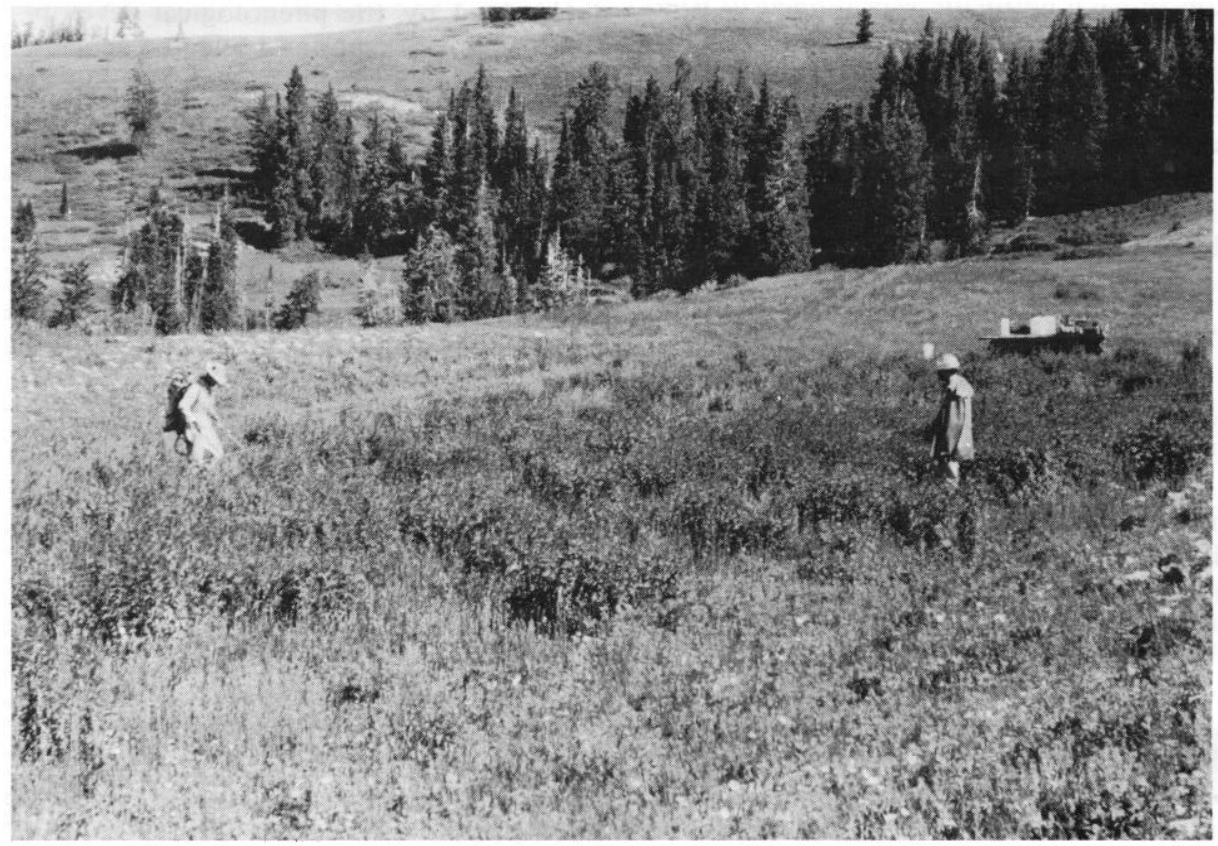

Fig. 1. Applying herbicide treatments to plots in a patch of tall larkspur in the subalpine zone of the Wasatch Plateau. 
florum Pursh.) was past flowering, but the leaves remained green and turgid. Nuttall violet (Viola nuttallii Pursh.) and common rock-jasminc (Androsace septentrionalis L.) were in full bloom. Meadow cinquefoil (Potentilla gracilis Dougl.) and Colorado columbine (Aquilegia caerulea James) were starting to bloom.

An ocular point frame was used to estimate changes in vegetation as a result of herbicides applied (Cronin and Nielsen, 1972). Ten samples of 10 points each (100 points/plot/year), spaced $3 \mathrm{ft}$ apart along the axis of the 8-by $33-\mathrm{ft}$ plots, wcre obtained on each plot before treatment and annually for 4 or more years after treatment. The first species or object intercepted by the line of sight was recorded for each point. The exception was in the 1965 experiment, when 200 points ( 20 points for each of 10 samples) were obtained annually for each plot. Only changes in the density of tall larkspur are reported here, but detrimental reductions of forage or potential erosion hazards caused by any treatment were also recorded.

Data from each experiment was subjected to analysis of variance, and when significant differences caused by treatment were indicated, Duncan's new multiple-range test was applied.

\section{Study}

The purpose of this study was to determine the relative effectiveness of 2,4,5-T and silvex, and whether the lowvolatile esters or the oil-soluble amines of these herbicides were more toxic to tall larkspur. A randomized-block design was treated with the propylene glycol butylether ester or the diethylamine salt of both 2,4,5-T and silvex. Each formulation of each herbicide was applied to four replications at rates of 4 or $8 \mathrm{lb} /$ acre of the active ingredient. One plot in each block remained untreated as a check plot. All plots were inside an exclosure at 9,800 $\mathrm{ft}$ near the head of Manti Canyon of the Wasatch Plateau in central Utah. Herbicide treatments were applied July $11,1963$.

\section{Study}

The objectives of this study were to evaluate the toxicity of dicamba $(3,6-$ dichloro-o-anisic acid) and of high rates (16 lb/acre) of $2,4,5-\mathrm{T}$ to tall larkspur and associated species; and to determine the longevity of soil sterilization resulting from applications of abnormally high rates of picloram (4-amino 3,5,6-trichloropicolinic acid). The propylene glycol butyl ether ester of 2,4,5-T was applied at 4,8 , and $16 \mathrm{lb} /$ acre of active ingredient. The diethylamine salt of dicamba and the potassium salt of picloram were applied at rates of 2,4 , and $8 \mathrm{lb} /$ acre of active ingredient. All treatments and the untreated check were replicated four times
Table 1. Treatments applied to the 1965 study plots in 1965,1966 , and 1967.

\begin{tabular}{|c|c|c|c|c|c|}
\hline \multicolumn{4}{|c|}{ Treatments } & \multirow{3}{*}{$\begin{array}{l}\text { Number of } \\
\text { applications } \\
\text { made }\end{array}$} & \multirow{3}{*}{$\begin{array}{c}\text { Total amount } \\
\text { of herbicide } \\
\text { applied (lb/acre) }\end{array}$} \\
\hline \multirow{2}{*}{$\begin{array}{c}\text { Herbicide } \\
\text { applied }\end{array}$} & \multicolumn{3}{|c|}{ Rate applied ${ }^{1}$ in: } & & \\
\hline & 1965 & 1966 & 1967 & & \\
\hline \multicolumn{4}{|c|}{ Check-no treatment applied } & 0 & 0 \\
\hline $2,4,5-T$ & 8 & 0 & 0 & 1 & 8 \\
\hline $2,4,5-\mathrm{T}$ & 4 & 4 & 0 & 2 & 8 \\
\hline $2,4,5-\mathrm{T}$ & 4 & 8 & 0 & 2 & 12 \\
\hline $2,4,5-\mathrm{T}$ & 8 & 8 & 0 & 2 & 16 \\
\hline $2,4,5-\mathrm{T}$ & 2 & 4 & 4 & 3 & 10 \\
\hline $2,4,5-\mathrm{T}$ & 4 & 4 & 4 & 3 & 12 \\
\hline $2,4,5-\mathrm{T}$ & 2 & 4 & 8 & 3 & 14 \\
\hline Silvex & 2 & 4 & 4 & 3 & 10 \\
\hline $2,4-\mathrm{D}$ & 8 & 8 & 8 & 3 & 24 \\
\hline Dicamba & 1 & 1 & 1 & 3 & $\begin{array}{r}24 \\
3\end{array}$ \\
\hline Dicamba & 2 & 2 & 2 & 3 & 6 \\
\hline Picloram & $1 / 4$ & $1 / 4$ & $1 / 4$ & 3 & $3 / 4$ \\
\hline Picloram & $1 / 2$ & $1 / 2$ & $1 / 2$ & 3 & $11 / 2$ \\
\hline $2,4,5-\mathrm{T}$ plus $2,4-\mathrm{D}$ & $2+2$ & $2+2$ & $2+2$ & 3 & $6+6$ \\
\hline $2,4,5-\mathrm{T}$ plus $2,4-\mathrm{D}$ & $4+2$ & $4+2$ & $4+2$ & 3 & $12+6$ \\
\hline
\end{tabular}

${ }^{1}$ Rate of herbicide application indicate amount (lb/acre) of active ingredient applied. in a completely randomized design. Plots were on a level site at $8,500 \mathrm{ft}$ in Hougaard Fork of Manti Canyon.

\section{Study}

This experiment was designed to evaluate various split or annualiy repeated applications of $2,4,5-\mathrm{T}$, silvex, dicamba, 2,4-D [2,4-dichlorophenoxy) acetic acid] picloram, and mixtures of 2,4-D and $2,4,5-\mathrm{T}$. Four replications of the treatments and the untreated check plots were in a randomized-block design. Most of the treatments for this experiment involved applications repeated annually for 2 or 3 years. The names and total amounts of hcrbicides applied are shown in Table 1. Treatments were applied on July 14, 1965 , July 8, 1966, and July 20,1967, as determined by the phenological development of tall larkspur and selected species. Plots were on a snowdrift area at 9,800 ft and were grazed by cattle.

\section{Results and Discussion}

Although changes in the densities of all plant species and the percent bare ground were recorded on each sampling date and will be reported in detail later, only the changes in densities of tall larkspur are reported here. However, it may be assumed that herbicide treatments increased forage production and did not significantly increase the percent bare ground unless noted in the following discussion.

\section{Srudy}

Significant differences between herbicides and rates applied existed in 1964 , but these differences had disappeared by 1965 (Table 2). Densities of tall larkspur remained significantly lower on all herbicide-treated plots, except for plots treated with the ester of 2,4,5-T at 4 $\mathrm{lb} / \mathrm{acre}$, than on the untreated check plots until 1966. Single applications of these herbicides seldom produce significant differences beyond the season after application. Protection afforded by the ex-
Table 2. Percent cover of tall larkspur for each sampling year on plots treated July $11,1963 .^{1}$

\begin{tabular}{|c|c|c|c|c|c|c|c|}
\hline \multicolumn{3}{|c|}{ Treatment applied } & \multirow{2}{*}{\multicolumn{5}{|c|}{ Year sampled $^{2}$}} \\
\hline \multirow[b]{2}{*}{ Herbicide } & \multirow[b]{2}{*}{ Formulation } & \multirow{2}{*}{$\begin{array}{c}\text { Rate } \\
\text { (lb/acre) }\end{array}$} & & & & & \\
\hline & & & 1963 & 1964 & 1965 & 1966 & 1968 \\
\hline Check & none & 0 & $11 \mathrm{a}$ & $11 \mathrm{c}$ & $10 \mathrm{~b}$ & $8 \mathrm{a}$ & $9 a$ \\
\hline $2,4,5-\mathrm{T}$ & ester ${ }^{3}$ & 4 & $14 \mathrm{a}$ & $10 \mathrm{bc}$ & $8 \mathrm{ab}$ & $11 \mathrm{a}$ & $12 \mathrm{a}$ \\
\hline Silvex & ester ${ }^{3}$ & 4 & $13 \mathrm{a}$ & $3 a b$ & $4 a$ & $5 a$ & $4 \mathrm{a}$ \\
\hline $2,4,5-\mathrm{T}$ & amine $^{4}$ & 4 & $12 \mathrm{a}$ & $4 \mathrm{ab}$ & $4 \mathrm{a}$ & $7 \mathrm{a}$ & $8 \mathrm{a}$ \\
\hline Silvex & amine 4 & 4 & $12 \mathrm{a}$ & $3 a b$ & $4 a$ & $4 \mathrm{a}$ & $7 \mathrm{a}$ \\
\hline $2,4,5-\mathrm{T}$ & ester ${ }^{3}$ & 8 & $10 \mathrm{a}$ & $4 a b$ & $4 \mathrm{a}$ & $3 a$ & $3 a$ \\
\hline Silvex & ester ${ }^{3}$ & 8 & $11 \mathrm{a}$ & $1 \mathbf{a}$ & $3 a$ & $2 \mathrm{a}$ & $3 a$ \\
\hline $2,4,5-\mathrm{T}$ & $\operatorname{amine}^{4}$ & 8 & $13 \mathrm{a}$ & $4 \mathrm{ab}$ & $4 a$ & $6 \mathrm{a}$ & $5 \mathrm{a}$ \\
\hline Silvex & amine $^{4}$ & 8 & $13 \mathrm{a}$ & $6 \mathrm{ab}$ & $6 a$ & $9 \mathrm{a}$ & 8 a \\
\hline
\end{tabular}

${ }^{1}$ Each value represents the average of four replications of each treatment.

${ }^{2}$ Means in the same column followed by the same letter are not significantly different at the $5 \%$ level.

${ }^{3}$ Propylene glycol butyl ether esters.

${ }^{4}$ Diethylamine. 
Table 3. Percent of tall larkspur cover for each sampling year on plots receiving herbicide treatments on July $16,1964 .^{1}$

\begin{tabular}{ccccccc}
\hline \hline $\begin{array}{c}\text { Herbicide } \\
\text { applied }\end{array}$ & $\begin{array}{c}\text { Rate } \\
\text { applied } \\
\text { (lb/acre) }\end{array}$ & 1964 & 1965 & 1966 & 1967 & 1968 \\
\hline Check & - & $15 \mathrm{a}$ & $23 \mathrm{~b}$ & $24 \mathrm{c}$ & $23 \mathrm{c}$ & $19 \mathrm{~b}$ \\
$2,4,5-\mathrm{T}$ & 4 & $17 \mathrm{ab}$ & $2 \mathrm{a}$ & $2 \mathrm{ab}$ & $3 \mathrm{a}$ & $2 \mathrm{a}$ \\
$2,4,5-\mathrm{T}$ & 8 & $16 \mathrm{ab}$ & $0 \mathrm{a}$ & $0 \mathrm{a}$ & $1 \mathrm{a}$ & $1 \mathrm{a}$ \\
$2,4,5-T$ & 16 & $21 \mathrm{~b}$ & $0 \mathrm{a}$ & $0 \mathrm{a}$ & $1 \mathrm{a}$ & $0 \mathrm{a}$ \\
Dicamba & 2 & $12 \mathrm{a}$ & $18 \mathrm{~b}$ & $16 \mathrm{bc}$ & $20 \mathrm{c}$ & $17 \mathrm{~b}$ \\
Dicamba & 4 & $14 \mathrm{a}$ & $12 \mathrm{ab}$ & $1 \mathrm{abc}$ & $14 \mathrm{bc}$ & $8 \mathrm{ab}$ \\
Dicamba & 8 & $16 \mathrm{ab}$ & $4 \mathrm{a}$ & $4 \mathrm{ab}$ & $6 \mathrm{a}$ & $3 \mathrm{a}$ \\
Picloram & 2 & $13 \mathrm{a}$ & $0 \mathrm{a}$ & $0 \mathrm{a}$ & $0 \mathrm{a}$ & $0 \mathrm{a}$ \\
Picloram & 4 & $14 \mathrm{a}$ & $0 \mathrm{a}$ & $0 \mathrm{a}$ & $0 \mathrm{a}$ & $0 \mathrm{a}$ \\
Picloram & 8 & $21 \mathrm{ab}$ & $0 \mathrm{a}$ & $0 \mathrm{a}$ & $0 \mathrm{a}$ & $0 \mathrm{a}$ \\
\hline
\end{tabular}

${ }^{1}$ Each value represents the averages of four replications of each treatment.

${ }^{2}$ Means in the same column followed by the same letter are not significantly different at the $1 \%$ level.

closure contributed to the duration of differences measured here.

Because applications of 2,4,5-T or silvex were equally effective for controlling tall larkspur, either formulation of herbicide could be substituted freely without significantly changing the results. Applications of $4 \mathrm{lb} /$ acre of either herbicide produced results equal to applications of $8 \mathrm{lb} /$ acre of active ingredient.

\section{Study}

Typically, single applications of either 4 or $8 \mathrm{lb} / \mathrm{acre}$ of active ingredient of 2,4,5-T had significantly reduced the density of tall larkspur for 1 or at most 2 years, as recorded in the 1963 study. However, treatments of 2,4,5-T in 1964 produced significant reductions that persisted through 1968, when these plots were last sampled (Table 3). Environmental conditions and phenological development of the plants were similar when treatments were applied throughout this period. No explanation for the variation in response of tall larkspur was evident. It was evident, however, that such long-term reductions could not be achieved consistently with one application of either 2,4,5-T or silvex, and a single application of one of these herbicides should not be relied on for controlling tall larkspur.

Applications of $16 \mathrm{lb} / \mathrm{acre}$ of 2,4,5-T did not reduce the density of tall larkspur significantly more than did 4 or $8 \mathrm{lb} /$ acre. Applications of 2 and $4 \mathrm{lb} /$ acre of active ingredient of dicamba produced results similar to those from treatments with 2,4,5-T. Densities of tall larkspur remained lower on treated than on the untreated check plots until the third and fourth season after the treatments were applied. Even as late as 1968, the density of tall larkspur on plots treated with 8 $\mathrm{lb} / \mathrm{acre}$ of active ingredient of dicamba was not significantly different from den-

Table 4. Percent cover of tall larkspur on plots before treatment in 1965 and for each sampling year following. ${ }^{1}$

\begin{tabular}{|c|c|c|c|c|c|c|c|c|}
\hline \multicolumn{4}{|c|}{ Treatment } & \multirow{2}{*}{\multicolumn{5}{|c|}{ Year sampled $^{2}$}} \\
\hline \multirow{2}{*}{$\begin{array}{l}\text { Applied } \\
\text { herbicide }\end{array}$} & \multicolumn{3}{|c|}{ Rate (lb/acre) applied } & & & & & \\
\hline & 1965 & 1966 & 1967 & 1965 & 1966 & 1967 & 1968 & 1970 \\
\hline Check & 0 & 0 & 0 & $26 a$ & $46 d$ & $26 \mathrm{e}$ & $34 \mathrm{c}$ & $24 \mathrm{~d}$ \\
\hline 2,4-D & 8 & 8 & 8 & $28 a$ & $31 \mathrm{bcd}$ & $16 \mathrm{~d}$ & $12 \mathrm{~b}$ & $15 \mathrm{c}$ \\
\hline Dicamba & 2 & 2 & 2 & $28 \mathrm{a}$ & $34 \mathrm{~cd}$ & $11 \mathrm{~cd}$ & $12 \mathrm{~b}$ & $7 \mathrm{~b}$ \\
\hline $2,4,5-\mathrm{T}$ & 8 & 0 & 0 & $18 \mathrm{a}$ & $11 \mathrm{a}$ & $7 \mathrm{bc}$ & $11 \mathrm{~b}$ & $6 \mathrm{~b}$ \\
\hline Picloram & $1 / 4$ & $1 / 4$ & $1 / 4$ & $24 \mathrm{a}$ & $34 \mathrm{~cd}$ & $12 \mathrm{~cd}$ & $5 \mathrm{a}$ & $4 a b c$ \\
\hline $2,4,5-\mathrm{T}$ & 8 & 8 & 0 & $23 \mathrm{a}$ & $15 \mathrm{abc}$ & $1 \mathrm{ab}$ & $0 \mathrm{a}$ & $4 \mathrm{abc}$ \\
\hline Dicamba & 1 & 1 & 1 & $20 \mathrm{a}$ & $24 \mathrm{abc}$ & $10 \mathrm{~cd}$ & $8 \mathrm{ab}$ & $3 \mathrm{ab}$ \\
\hline $2,4,5-\mathrm{T}$ & 4 & 8 & 0 & $20 a$ & $11 \mathrm{a}$ & $2 a b$ & $1 \mathrm{a}$ & $1 \mathrm{a}$ \\
\hline $2,4,5-\mathrm{T}$ & 4 & 4 & 0 & $19 \mathrm{a}$ & $11 \mathrm{a}$ & $0 \mathrm{a}$ & $4 \mathrm{ab}$ & $0 \mathrm{a}$ \\
\hline Picloram & $1 / 2$ & $1 / 2$ & $1 / 2$ & $21 \mathrm{a}$ & $16 a b c$ & $4 \mathrm{ab}$ & $1 \mathrm{a}$ & $0 \mathrm{a}$ \\
\hline Silvex & 2 & 4 & 4 & $27 \mathrm{a}$ & $11 \mathrm{a}$ & $0 \mathrm{a}$ & $0 \mathrm{a}$ & $0 \mathrm{a}$ \\
\hline $2,4,5-\mathrm{T}$ & 2 & 4 & 4 & $19 a$ & $26 a b c$ & $0 \mathrm{a}$ & $0 \mathrm{a}$ & $0 \mathrm{a}$ \\
\hline $2,4,5-\mathrm{T}$ & 2 & 4 & 8 & $29 a$ & $23 \mathrm{abc}$ & $2 a b$ & $0 \mathrm{a}$ & $0 \mathrm{a}$ \\
\hline $2,4,5-\mathrm{T}$ & 4 & 4 & 4 & $30 \mathrm{a}$ & $26 a b c$ & $1 \mathrm{ab}$ & $0 \mathrm{a}$ & $0 \mathrm{a}$ \\
\hline $2,4,5-\mathrm{T}$ plus $2,4-\mathrm{D}$ & $2+2$ & $2+2$ & $2+2$ & $31 \mathrm{a}$ & $24 a b c$ & $3 a b$ & $0 \mathrm{a}$ & $0 \mathrm{a}$ \\
\hline $2,4,5-\mathrm{T}$ plus $2,4-\mathrm{D}$ & $4+2$ & $4+2$ & - $4+2$ & $21 \mathrm{a}$ & $23 \mathrm{abc}$ & $2 a b$ & $0 \mathrm{a}$ & $0 \mathrm{a}$ \\
\hline
\end{tabular}

${ }^{1}$ Each value represents the averages of four replications of each treatment.

${ }^{2}$ Means in the same column followed by the same letter are not significantly different at the $1 \%$ level. sities on plots treated with 2,4,5-T.

The three rates of applications of picloram reduced the density of tall larkspur to zero, but, as expected, picloram sterilized the soil. Tansymustard [Descurainia pinnata (Walt.) Britton] and letterman needlegrass (Stipa lettermani Vasey) were the first plants to appear on these plots, but by 1968 many good forage species were growing on these plots. By 1968 bare ground had been reduced to $53 \%, 58 \%$, and $69 \%$ for the 2 , 4 , and $8 \mathrm{lb} /$ acre of active ingredient treatments respectively. This compared with $18 \%$ bare ground on the untreated check plots and $35 \%$ on the plots treated with $8 \mathrm{lb} / \mathrm{acre}$ of active ingredient of $2,4,5-\mathrm{T}$.

\section{Study}

Most split treatments effectively reduced the density of tall larkspur. One $\mathrm{lb} / \mathrm{acre}$ of dicamba applied each summer, both split treatments with picloram, and all split treatments with $2,4,5-\mathrm{T}$ were equally effective as late as 1970 (Table 4). Picloram has not yet been registered for use on grazing lands, and, therefore, cannot be recommended at this time. Only one split treatment was evaluated, but results from other experiments (Cronin and Nielsen, 1972) and the 1963 study reported here indicate silvex could be substituted for 2,4,5-T in any of thesc split treatments without significantly changing the results.

\section{Conclusions}

The options provided by the many effective treatments for controlling tall larkspur should be considered before choosing a particular herbicide treatment. The treatment should increase the production of the associated forage species. Higher rates of chemicals such as picloram should be avoided on sloping snowdrift sites, because of the high erosion potential (Ellison, 1954). The cost of the various herbicide treatments should be an important factor in selecting a particular treatment. The cost of the herbicides applied was small compared to the anticipated cost of applying them to relative small patches of tall larkspur scattered over rough terrain. Therefore, methods of treatment involving the smallest number of applications offered substantial financial reward.

These criteria indicated that two annual applications of $4 \mathrm{lb} / \mathrm{acre}$ of active ingredient of 2,4,5-T or silvex should be selected for controlling tall larkspur on subalpine grazing land (Fig. 2). The re- 


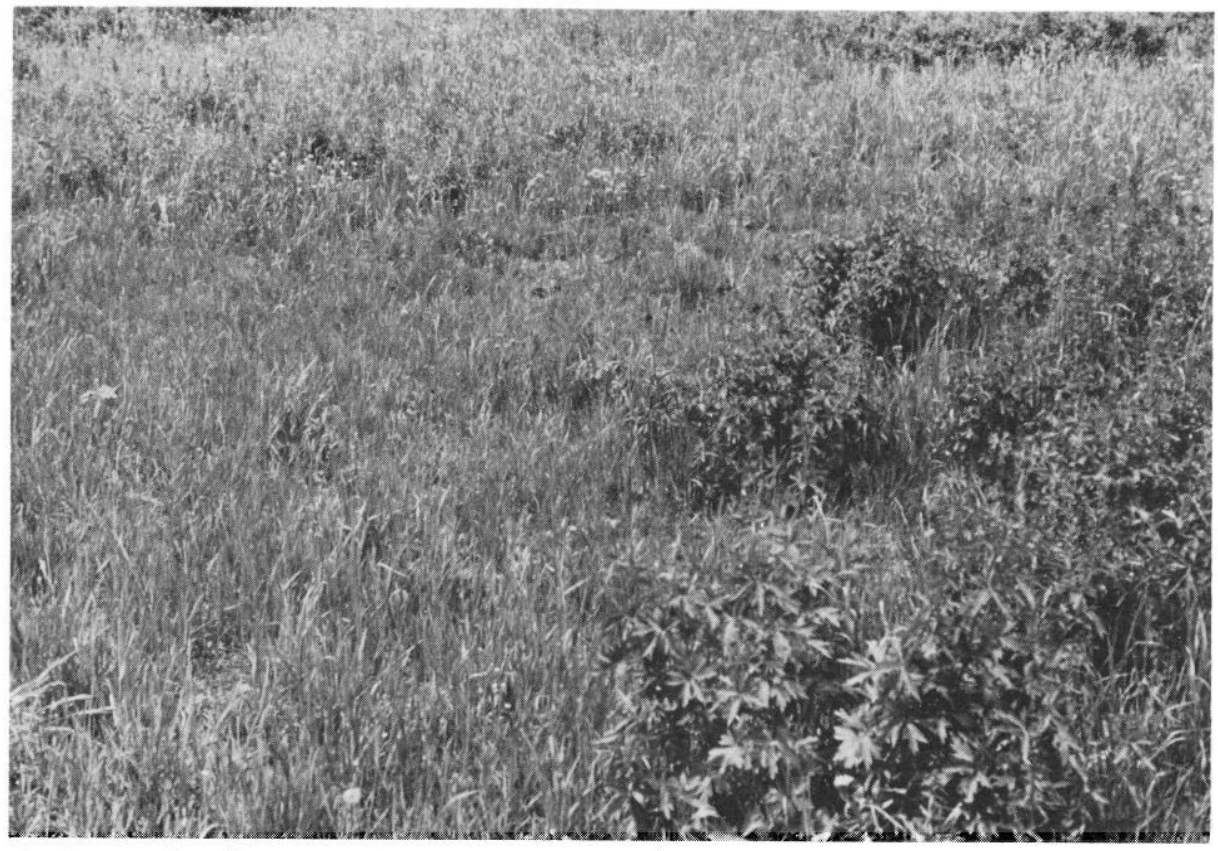

Fig. 2. Results of two annual treatments with $4 \mathrm{lb} /$ acre of 2,4,5-T on the left contrasted with the untreated control plot on the right. sponse of the associated vegetation has been favorable, and no other treatment has resulted in significantly higher grass production. Control of tall larkspur should permit proper management of these subalpine pastures for improved quality and production of forage.

\section{Literature Cited}

Clarke, D. E., and J. S. Palmer. 1971. Residual aspects of 2,4,5-T and ester in sheep and cattle concomitant toxicological effects. J. Agr. Food Chem. 19:761-764.

Cronin, E. H. 1971. Tall larkspur and its continuing preeminence as a poisonous plant. J. Range Manage. 24:258-263.

Cronin, E. H., and D. B. Nielsen. 1972. Controlling tall larkspur on snowdrift areas in the subalpine zone. J. Range Manage. 25:213-216.

Ellison, Lincoln. 1954. Subalpine vegetation of the Wasatch Plateau, Utah. Ecol. Mongr. 24:89-183.

Kingsbury, J. M. 1964. Poisonous plants of the United States and Canada. Prentice-Hall Inc., Englewood Cliffs, N. J. 626 p.

\section{밈ㅁ}
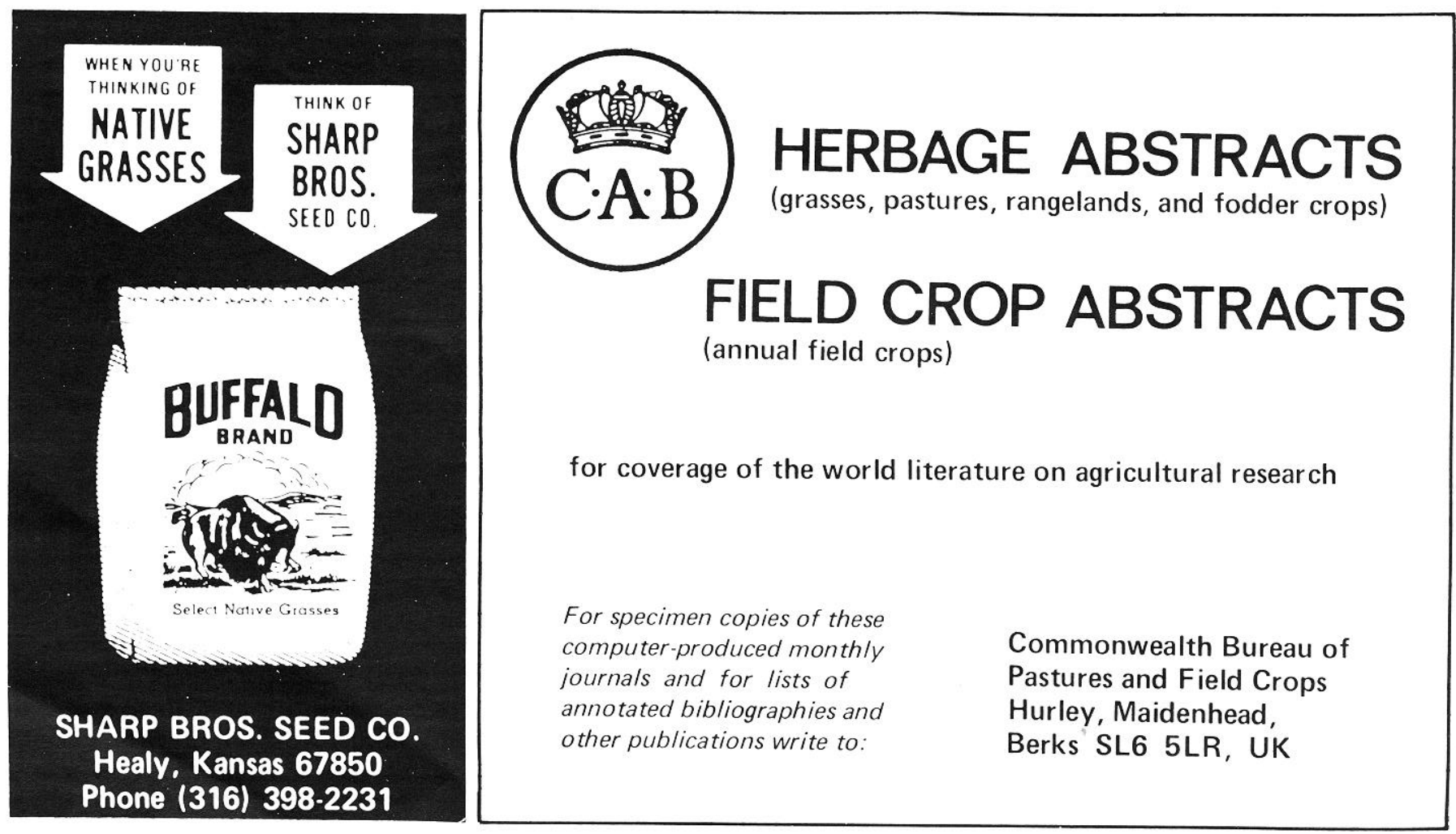